\title{
Capacity enhancement of hepatitis C virus treatment through integrated, community-based care
}

\author{
Warren D Hill PhD, Gail Butt RN MHSc, Maria Alvarez MSc, Mel Krajden MD FRCPC
}

WD Hill, G Butt, M Alvarez, M Krajden. Capacity enhancement of hepatitis $\mathrm{C}$ virus treatment through integrated, communitybased care. Can J Gastroenterol 2008;22(1):27-32.

BACKGROUND: An estimated 250,000 Canadians are infected with the hepatitis $\mathrm{C}$ virus (HCV). The present study describes a cohort of individuals with HCV referred to community-based, integrated prevention and care projects developed in British Columbia. Treatment outcomes are reported for a subset of individuals undergoing antiviral therapy at four project sites.

METHODS: Four demonstration projects based on a public health nurse and physician partnership were established in rural and small urban centres in British Columbia. Comprehensive medical assessments determined whether individuals received treatment, or counselling and education. Outcomes of the treatment group were compared with published randomized controlled trials. Client demographics were mapped using geographical information systems applications.

RESULTS: A total of 1795 individuals were referred to the clinics for medical assessment between Septmber 2001 and December 2005. After assessment, 26\% were eligible for therapy, while $74 \%$ received counselling and education. Wait times decreased annually, with onehalf of all referrals assessed within 30 days. Combination antiviral therapy was initiated in 363 clients with interferon plus ribavirin $(n=36)$ or pegylated interferon plus ribavirin $(n=327)$. Treatment outcomes were available for 205 individuals. The overall rate of sustained virological response was $61 \%$ ( 126 of 205 individuals). The number of individuals assessed at each site represented, on average, $20 \%$ of the total cumulative reported HCV cases in the catchment areas.

DISCUSSION: The study findings illustrate how a public health nurse and physician partnership can service a population with complex medical needs while simultaneously increasing local capacity. Treatment outcomes were comparable with published clinical trials.

Key Words: Capacity enhancement; HCV treatment; Hepatitis C virus

C Thronic hepatitis $\mathrm{C}$ virus (HCV) infection affects over 250,000 Canadians, of whom only two-thirds have been identified (1). Approximately $10 \%$ to $25 \%$ of those infected will develop cirrhosis, end-stage liver disease, hepatocellular carcinoma or require liver transplantation in the coming decades (2,3). Canada currently spends approximately $\$ 500$ million per year on HCV. With an estimated 5000 new infections occurring annually, spending on $\mathrm{HCV}$ and its sequelae is expected to reach $\$ 1$ billion per year by 2010 (4). Pegylated interferon plus ribavirin, the current standard therapy, produces sustained virological response (SVR), ie, viral clearance, in $45 \%$ to $80 \%$ of treated individuals, depending

\section{L'amélioration de la capacité dans le traitement du virus de l'hépatite $\mathrm{C}$ par des soins communautaires intégrés}

HISTORIQUE : On estime que 250000 Canadiens sont infectés par le virus de l'hépatite $\mathrm{C}(\mathrm{VHC})$. La présente étude décrit une cohorte d'individus atteints de $\mathrm{VHC}$ aiguillés vers des projets de prévention et de soins communautaires intégrés, mis au point en Colombie-Britannique. Les issues des traitements sont déclarées pour un sous-groupe de personnes subissant une antivirothérapie dans quatre établissements du projet.

MÉTHODOLOGIE : On a mis sur pied quatre projets pilotes fondés sur un partenariat entre une infirmière de santé publique et un médecin des centres ruraux et de petits centres urbains de la Colombie-Britannique. Des évaluations médicales complètes ont permis de déterminer si les personnes recevaient un traitement ou des conseils et de l'information. On a comparé les issues du groupe traité à celles d'essais aléatoires et contrôlés publiés. On a établi la démographie des clients d'après les applications des systèmes d'information géographique.

RÉSULTATS : Au total, 1795 personnes ont été aiguillées vers les cliniques afin de subir une évaluation médicale entre septembre 2001 et décembre 2005. Après évaluation, $26 \%$ étaient admissibles au traitement, tandis que $74 \%$ ont reçu des conseils et de l'information. Les temps d'attente ont diminué chaque année, la moitié des aiguillages étant évalués dans les 30 jours. On a entrepris une antivirothérapie d'association chez 363 clients, composée d'interféron et de ribavirine ( $\mathrm{n}=36)$ ou d'interféron pégylé et de ribavirine $(\mathrm{n}=327)$. On connaissait l'issue du traitement de 205 patients. Le taux global de réponse virologique soutenue s'élevait à $61 \%$ (126 des 250 patients). Le nombre de patients évalués dans chaque établissement correspondait, en moyenne, à $20 \%$ des cas du total cumulatif de cas de VHC déclarés dans les zones desservies.

DISCUSSION : Les résultats de l'étude démontrent qu'un partenariat avec une infirmière de santé publique et un médecin peut servir une population aux besoins médicaux complexes tout en accroissant la capacité locale. Les issues des traitements étaient comparables à celles des essais cliniques publiés.

BC Centre for Disease Control, Vancouver, British Columbia

Correspondence: Dr Mel Krajden, BC Centre for Disease Control, 655 West 12th Avenue, Vancouver, British Columbia V5Z 4 R4.

Telephone 604-660-6044, fax 604-660-2094, e-mail mel.krajden@bccdc.ca

Received for publication March 19, 2007. Accepted July 9, 2007 
been shown to be a cost-effective way of reducing overall disease mortality and morbidity (10).

In Canada and other developed countries, the majority of existing HCV infections (68\% to $80 \%$ ) were acquired by remote or recent injection drug use (IDU), approximately $15 \%$ from contaminated blood products before donor testing for $\mathrm{HCV}$, and the remainder of the infections were acquired in countries with high HCV endemicity, from high-risk sexual activity, and by perinatal and occupational transmission $(1,11)$. Estimates of HCV prevalence among IDU individuals range from $50 \%$ to $95 \%$ (12), indicating that this group is most at risk for ongoing transmission. There is no vaccine to prevent HCV infection and, therefore, transmission must be prevented through targeted public health measures. Once infected, the sequelae of chronic liver inflammation can be reduced by treatment (11). Over the long term, reducing the burden of $\mathrm{HCV}$ requires a coordinated approach involving public health prevention initiatives, primary care and specialist services (13). Currently, it is estimated that only a small proportion of $\mathrm{HCV}$-infected individuals have ever been referred to a specialist for a consultation and follow-up $(14,15)$.

In 2001, to respond to the estimated 60,000 cases of chronic HCV in British Columbia, the provincial government established BC Hepatitis Services (BCHS) as a division of the $\mathrm{BC}$ Centre for Disease Control. The overall mandate of the BCHS is to implement prevention and control strategies for viral hepatitis and reduce disease burden. BCHS established four demonstration projects in rural and small urban centres in British Columbia to provide locally accessible, integrated hepatitis prevention and care services based on a public health nurse and physician partnership. The aims of the present report are to describe the cohort of individuals with HCV referred to the integrated prevention and care sites from 2001 to 2005 and report on treatment outcomes for a subset of individuals who initiated antiviral therapy.

\section{METHODS}

From 2001 to 2004, BCHS and its partners launched four integrated prevention and care demonstration projects in rural and small urban areas in British Columbia. Implementation was staged, allowing sites implemented later to learn from the experience of preceding sites. Each site received a $\$ 25,000$ start-up grant to define their program, as well as $\$ 75,000$ in annual funding. Nurses and allied health professionals completed an interdisciplinary training program that was organized and partially funded by BCHS. Participation in annual update sessions ensured that education requirements and competencies were maintained. Core partnerships for clinical services were formed between public health nurses and local physicians (between one and four physicians per site). Although medical decisions affecting clients on therapy were ultimately the responsibility of the individuals' physician of record, clinical management was enhanced by sharing of responsibility and decision-making between nurses and physicians. The project sites were located in Campbell River, Kamloops, Prince George and Surrey. The study cohort was derived from 1795 individuals referred to the project sites between September 1, 2001 and December 31, 2005.

Clients could be self-referred, or referred by physicians or allied health agencies (eg, street clinics). Clinic staff arranged for a nurse to interview each case as part of a comprehensive prevention and care assessment. Immunizations and referrals to ancillary services, such as mental health and addictions counselling, were offered where appropriate. An initial assessment determined the specific client needs. Eligibility for therapy was determined by the nurse and physician at the initial assessment or at a subsequent visit. Treatment criteria were determined in accordance with published Canadian guidelines for the management of $\mathrm{HCV}$ for clients initiating therapy after 2004 (16). Before 2004, treatment eligibility was determined by guidelines for the management of patients with HCV from the United States National Institutes of Health. Clients who were not eligible for therapy received education and counselling. For purposes of analysis, we divided clients into two groups: eligible for therapy, or for education and counselling.

Individuals who initiated therapy were analyzed based on viral genotypes: genotype 1 and genotype 2/3. To ensure an adequate period to evaluate for SVR by December 31, 2005, the outcome analysis included only those genotype 1 clients who started treatment before June 15, 2004. Using the same method, clients with genotype $2 / 3$ must have initiated therapy before December 31, 2004. This allowed each client to be observed for the period of time required to evaluate therapeutic response (ie, clients with genotype 1 were observed for 72 weeks and clients with genotype $2 / 3$ were observed for 48 weeks). All clients who initiated therapy before these cutoff dates were included in the analysis.

For study eligibility purposes, HCV infection was defined as a reactive anti-HCV antibody test and detection of HCV RNA by commercial qualitative or quantitative polymerase chain reaction assay. A successful outcome of therapy was a SVR defined as undetectable serum HCV RNA (less than $50 \mathrm{IU} / \mathrm{mL}$ ) by qualitative polymerase chain reaction assay (Cobas Amplicor HCV test, version 2.0, Roche Diagnostics, USA) six months after the end of treatment. SVR rates for the project sites were compared with those from published clinical trials.

To prospectively capture clinical and administrative data, a custom database was designed and used by each site. This database provided standardized data on demographic and disease characteristics, HCV RNA status on entry, mode of acquisition of $\mathrm{HCV}$, comorbid diseases, interventions, clinic resource utilization including duration and nature of health care contacts and the identity of the provider, clinical status and outcomes of therapy. Specific medical parameters, such as liver biopsy or laboratory test values, were not collected. To ensure data accuracy, the database incorporated a series of algorithms to identify missing and out-of-sequence data. All individual records were audited to confirm the accuracy of the dataset. Client-specific data were exported to the $\mathrm{BC}$ Centre for Disease Control at the end of each calendar year, without personal identifying information (ie, anonymously), and assigned a case number.

To assess the geographical catchment area of each project site, HCV cases reported to British Columbia's Integrated Public Health Information System from 1992 through 2004 were crossreferenced with the number of cases seen in each clinic site. Due to the site's late initiation date (January 2004), data from Surrey were not included in this portion of the analysis.

Differences in client demographics were assessed using $t$ tests for mean values, as well as ORs and $\chi^{2}$ for tests of proportions. Statistical analyses were performed using SPSS version 14.0 (SPSS Inc, USA). 


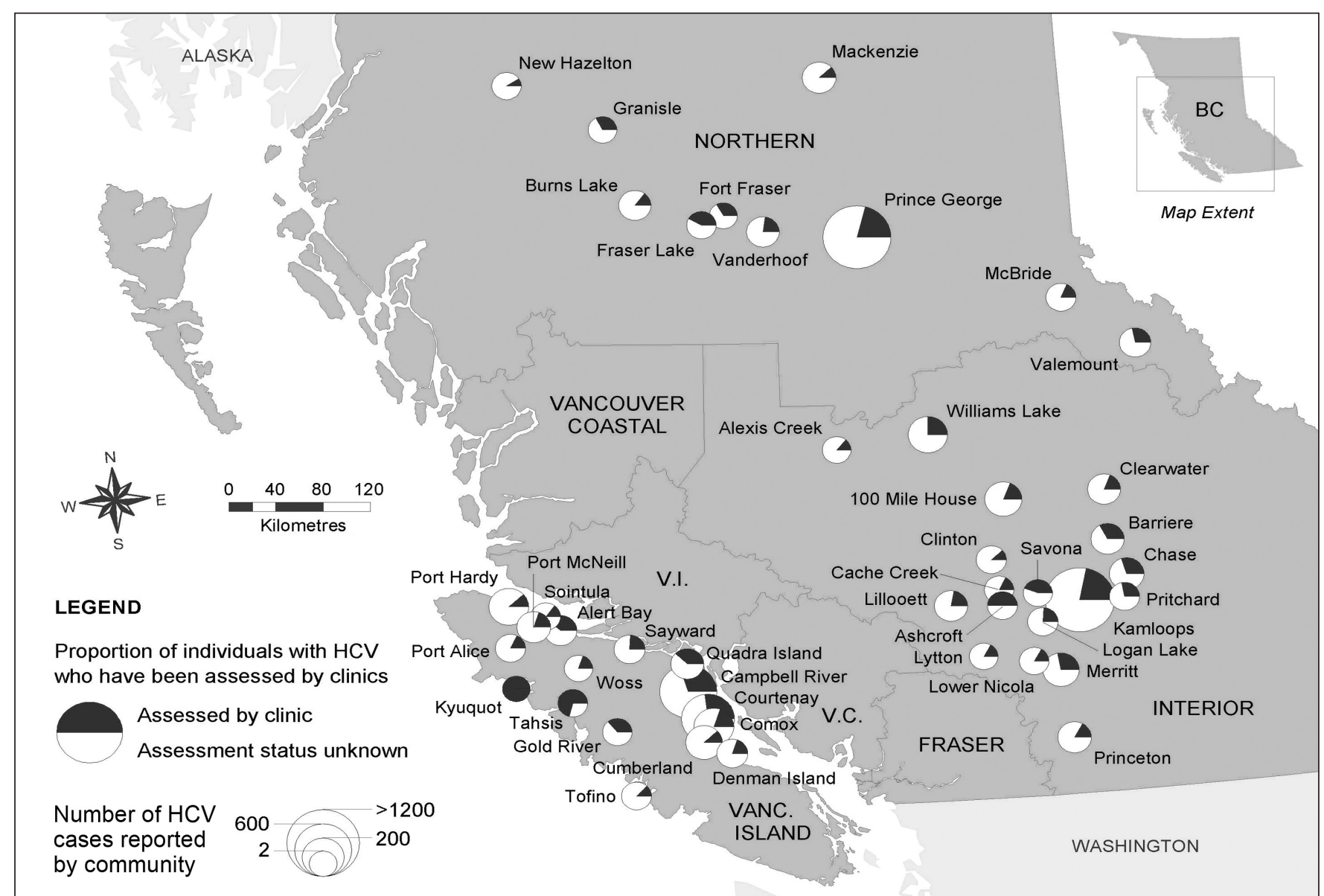

Figure 1) Hepatitis $\mathrm{C}$ virus (HCV) coverage in British Columbia (BC), defined as the number of individuals who received a medical assessment in one of the project sites, as a proportion of the total number of reported HCV cases for each community. Estimated total HCV case reports for 1992 to 2005 for each project site catchment area were: Kamloops (505 of 2206, 23\%); Prince George (309 of 1506, 21\%); and Campbell River (544 of 2124, 26\%). Only communities with three or more referrals to the regional clinic site were included in the catchment area calculations. Vanc Vancouver; V.C. Vancouver Coastal Health Authority; V.I. Vancouver Island Health Authority

\section{RESULTS}

The majority of funds allocated for the project were used to employ nurses in each of the four health regions. Existing physical infrastructure within public health units or regional hospitals was utilized to minimize overhead costs. A smaller proportion of funding was allocated to diversify harm prevention and reduction strategies. For example, one region employed a mental health and addictions counsellor, while another site allocated funds to physician sessional fees. One urban site partnered with local business and community leaders to develop a public education campaign on substance use and safe syringe disposal.

BCHS organized specialized training in viral hepatitis prevention and care for project staff through a series of intensive three-day interdisciplinary workshops held in Vancouver, British Columbia. Project staff subsequently delivered presentations to local agencies and groups. For example, one site provided a one-day workshop on viral hepatitis, which was attended by 16 physicians, and 105 nurses and allied health care workers.

Between September 2001 and December 2005, a total of 1795 individuals with HCV infection were referred to the integrated prevention and care sites for assessment. This represents approximately 3\% of all HCV cases reported in British Columbia between 1992 and 2005. Figure 1 demonstrates how the clinics (Kamloops, Campbell River and Prince George) have, on average, provided services to $20 \%$ to $25 \%$ of all reported $\mathrm{HCV}$ cases in the area serviced by each clinic.

The primary mode for acquiring HCV was IDU in the remote past, according to self-report. More than $95 \%$ of referrals were HCV RNA-positive on referral. The majority of clients were male and Caucasian (Table 1), with a significant proportion being Aboriginal (10\%). In comparison with clients who received education and counselling, clients eligible for therapy were almost two times more likely to be employed (OR 1.93, 95\% CI 1.53 to 2.44) and married (OR $1.74,95 \%$ CI 1.38 to 2.18).

The median time between referral and assessment was less than 30 days and the average wait time gradually decreased from 11.3 weeks in 2001 to 5.8 weeks in 2005. The number of annual referrals increased between 2001 and 2004 before declining in 2005 (Figure 2). Every year, the number of clients treated has increased.

Nurses were engaged in a wide range of activities and were the point of first contact for most clients $(82 \%)$. Nurses coordinated referrals and client intake, completed initial assessments and scheduled physician visits (if required). This nurse-coordinated approach made it possible to counsel and educate clients over the phone if necessary (eg, if a client could not attend the clinic), and determine the appropriate intake 
TABLE 1

Characteristics of clients eligible for therapy and clients eligible for education and counselling only

\begin{tabular}{|c|c|c|}
\hline Characteristic & $\begin{array}{l}\text { Clients eligible } \\
\text { for therapy }(n=471)\end{array}$ & $\begin{array}{l}\text { Clients eligible } \\
\text { for education } \\
\text { and counselling } \\
\text { only }(n=1324)\end{array}$ \\
\hline Male, n (\%) & $340(72)$ & $796(60)$ \\
\hline Mean age, years & 48.9 & $46.8(n=1318)$ \\
\hline \multicolumn{3}{|l|}{ Ethnic background, n/total (\%) } \\
\hline Caucasian & $418 / 460(91)$ & $860 / 1015(85)$ \\
\hline Asian & $16 / 460(3)$ & $39 / 1015(4)$ \\
\hline First Nations & $26 / 460(6)$ & $116 / 1015(11)$ \\
\hline \multicolumn{3}{|l|}{ Mode of infection, n/total (\%) } \\
\hline Intravenous drug use & $314 / 471(67)$ & $671 / 1233(54)$ \\
\hline Blood product before 1990 & $68 / 471(14)$ & $151 / 1233(12)$ \\
\hline Drug snorting or sharing equipment & ent $28 / 471(6)$ & $52 / 1233(4)$ \\
\hline Piercing and/or tattooing & $18 / 471(4)$ & $25 / 1233(2)$ \\
\hline Needle stick injury & $2 / 471(0.4)$ & $12 / 1233(1)$ \\
\hline Sexual transmission & $2 / 471(0.4)$ & $15 / 1233(1)$ \\
\hline Unknown/other & $39 / 471(8)$ & $307 / 1233(25)$ \\
\hline \multicolumn{3}{|l|}{ Employment status, n/total (\%) } \\
\hline Unemployed & $171 / 452(38)$ & $461 / 853(54)$ \\
\hline \multicolumn{3}{|l|}{ Marital status, n/total (\%) } \\
\hline Married & $263 / 471(56)$ & $390 / 1228(32)$ \\
\hline Single & $190 / 471(40)$ & $489 / 1228(40)$ \\
\hline Unknown/other & $18 / 471(4)$ & $349 / 1228(28)$ \\
\hline \multicolumn{3}{|l|}{ Hepatitis C virus genotype, n/total (\%) } \\
\hline 1 & $253 / 464(55)$ & $479 / 732(65)$ \\
\hline $2 / 3$ & $211 / 464(45)$ & $253 / 732(35)$ \\
\hline
\end{tabular}

Numerators and denominators presented in the table are based on available data

and referral pathways. Of the total nursing time, approximately $40 \%$ was occupied by telephone contact (2099 h of $5273 \mathrm{~h}$ ), $24 \%$ was devoted to client assessment (1242 h) and 13\% to patient education $(666 \mathrm{~h})$. Physician time was mainly devoted to clinical assessments (597 h of $1165 \mathrm{~h}, 51 \%$ ) and follow-up visits ( $524 \mathrm{~h}, 45 \%$ ). For both nurses and physicians, time spent on activities such as charting and professional training was not tracked.

The total number of individuals eligible to initiate therapy was 471 (26\%). The remaining 1324 clients (74\%) received education, monitoring and prevention counselling. Clients with indications for treatment were 1.6 times more likely to be genotype $2 / 3$ than those who received education, monitoring and prevention counselling (95\% CI 1.23 to 2.00). Individuals with indications for treatment had a higher number of health care contacts (ie, assessment plus follow-up visits) than those who received education and counselling (Table 2).

A small percentage of clients eligible for therapy ( 74 of 471 , $16 \%$ ) or receiving education and counselling (80 of 1324, 6\%) were referred to other health care providers during follow-up. Of these referrals, most were to mental health agencies (95 of $154,62 \%$ ), chemical dependency programs (30 of $154,19 \%$ ) and nutritional counselling (16 of 154,10\%). A small number of clients (nine of 154,6\%) were referred to a liver transplant clinic for further assessment.

Combination antiviral therapy was initiated in 363 clients, with either interferon plus ribavirin $(\mathrm{n}=36)$ or pegylated

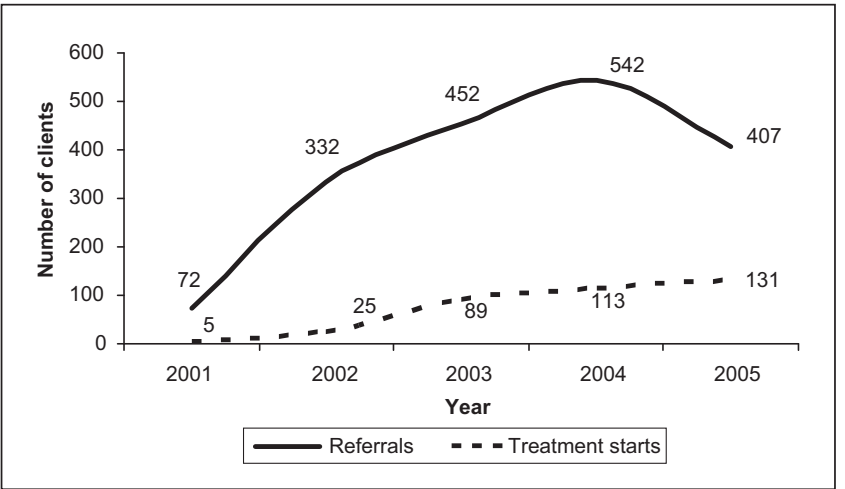

Figure 2) Total number of clients referred and starting treatment between 2001 and 2005

TABLE 2

Health care interactions of clients eligible for therapy and clients eligible for education and counselling only

\begin{tabular}{lcc}
\hline Health care interaction & $\begin{array}{c}\text { Clients } \\
\text { eligible for } \\
\text { therapy ( } \mathbf{n = 4 7 1 )}\end{array}$ & $\begin{array}{c}\text { Clients eligible } \\
\text { for education } \\
\text { and counselling } \\
\text { only ( } \mathbf{n = 1 3 2 4 )}\end{array}$ \\
\hline Attended clinic for assessment, $\mathrm{n}(\%)$ & $464(99)$ & $854(65)$ \\
$\quad$ Assessed by a physician, $\mathrm{n}(\%)$ & $391(83)$ & $518(39)$ \\
Assessed by a nurse, $\mathrm{n}(\%)$ & $428(91)$ & $804(61)$ \\
Time between referral and clinic & $4.0(2-8)$ & $4.8(2-10)$ \\
$\quad$ assessment, weeks & $32(21-45)$ & $7(4-11)$ \\
Health care contacts per client, $\mathrm{n}$ & $15(9-24)$ & $3(2-5)$ \\
Telephone contacts during follow-up, $\mathrm{n}$ & $175(90-280)$ & $25(10-42)$ \\
Telephone call minutes per client, $\mathrm{n}$ & $4(2-8)$ & $2(1-3)$ \\
Clinic visits per client, $\mathrm{n}$ & $90(50-180)$ & $30(15-60)$ \\
Clinic visit minutes per client, $\mathrm{n}$ &
\end{tabular}

Values are presented as the median (interquartile range) unless otherwise indicated

interferon plus ribavirin $(\mathrm{n}=327)$. Among these, 205 individuals had been observed for the period of time required to make an SVR determination (ie, 72 weeks for genotype 1 and 48 weeks for genotype $2 / 3$ ). The overall SVR rate was $61 \%$ (126 of 205). For genotype $1 \quad(n=98)$ and genotype $2 / 3$ $(n=107)$, the rate of SVR was $48 \%$ and $74 \%$, respectively. (Figure 3).

Therapy was unsuccessful in 39\% of clients (79 of 205). The reasons included treatment failure at week 12 in genotype 1 clients $(n=19)$, failure to sustain virological response (ie, viral relapse) $(n=18)$, adverse events $(n=15)$, end-oftreatment failure (ie, nonresponder) $(\mathrm{n}=14)$, patient choice $(n=8)$ and failure to return for a follow-up examination $(n=3)$ (Figure 3). Two clients died in this group, one from an unrelated cardiac event and the other of an unknown cause.

\section{DISCUSSION}

Because rates of $\mathrm{HCV}$ infection over the last few years are similar in each provincial health authority (average annualized rate for 1992 to 2005, 95.5/100,000 people [range, $82.1 / 100,000$ to $117.4 / 100,000$ people]), providing hepatitis services in multiple centres is critical to controlling and preventing the disease. However, before the creation of the project sites described here, services were often not locally available and expertise was concentrated in tertiary referral 
centres. The large number of individuals who received hepatitis services in the project sites demonstrates a high demand for locally available prevention and care resources. In following a cohort of individuals with HCV referred from 2001 to 2005, we observed that local provision of comprehensive hepatitis services reduced the time between referral and assessment.

Across all project sites, the time from referral to assessment decreased substantially in the first and second years of clinic operations, and the number of clients starting treatment increased. This suggests that the efficiency of health service delivery and capacity improved as staff gained experience. At each individual site, referral to assessment time was reduced after the first year and stabilized thereafter; the number of referrals peaked after the second year. The decline in referrals after the second year could be explained if a backlog of cases was present and subsequently evaluated by the clinics.

Of all clients who received a comprehensive medical assessment, 20\% (363 of 1795) initiated therapy. These data are consistent with a study that showed that only a small percentage of those with chronic HCV infection undergo antiviral therapy (7). A large percentage of the individuals who initiated therapy completed a full course $(79 \%)$; reasons for discontinuation of therapy were similar to those reported in the literature (17). SVR rates observed were consistent with results from published clinical trials $(5,6,18,19)$.

Unemployment rates were high among the treated, and the education and counselling groups. Of note, those who initiated treatment were nearly twice as likely to be employed, although this was not a specific criteria for eligibility, given that drug costs were publicly funded. This suggests that factors other than therapeutic costs may also affect initiation of therapy.

Clinical guidelines recommend a positive HCV RNA to confirm active infection before making a referral for specialty care. In the present study population, less than $5 \%$ of all referrals were HCV RNA-negative on referral to the clinic. This contrasts with a tertiary specialty care clinic in Manitoba, where a total of $18.5 \%$ of patients referred for assessment were HCV RNA-negative (17). More data are required to confirm whether this difference is attributable to local referral patterns or to greater adherence to clinical guidelines. In the project sites, conducting initial nursing assessments before physician or specialist consults may have reduced the number of inappropriate or unnecessary referrals.

Geographical access to medical care in France affects the rate of diagnosis of $\mathrm{HCV}$ infection, where $\mathrm{HCV}$ detection rates are lower in rural areas and rural patients are more frequently diagnosed with end-stage liver diseases, such as hepatocellular carcinoma (20). A concern exists that HCV care may also be inadequate in rural settings in Canada. The geomapping exercise was designed to identify the geographical catchment area of each project site, map the cumulative number of reported HCV cases, and define the proportion of cases assessed in the project sites. The results showed that the project sites, all serving rural populations, have assessed $20 \%$ to $25 \%$ of all reported HCV cases within their catchment areas. While this result is impressive in light of the overall burden of disease, it is not known whether the remaining $\mathrm{HCV}$ cases have received appropriate care.

To reduce the long-term sequelae of HCV, treatment capacity will need to be enhanced as therapies become increasingly individualized. The number of patients eligible for treatment is expected to rise as HCV therapies improve (21). Those who

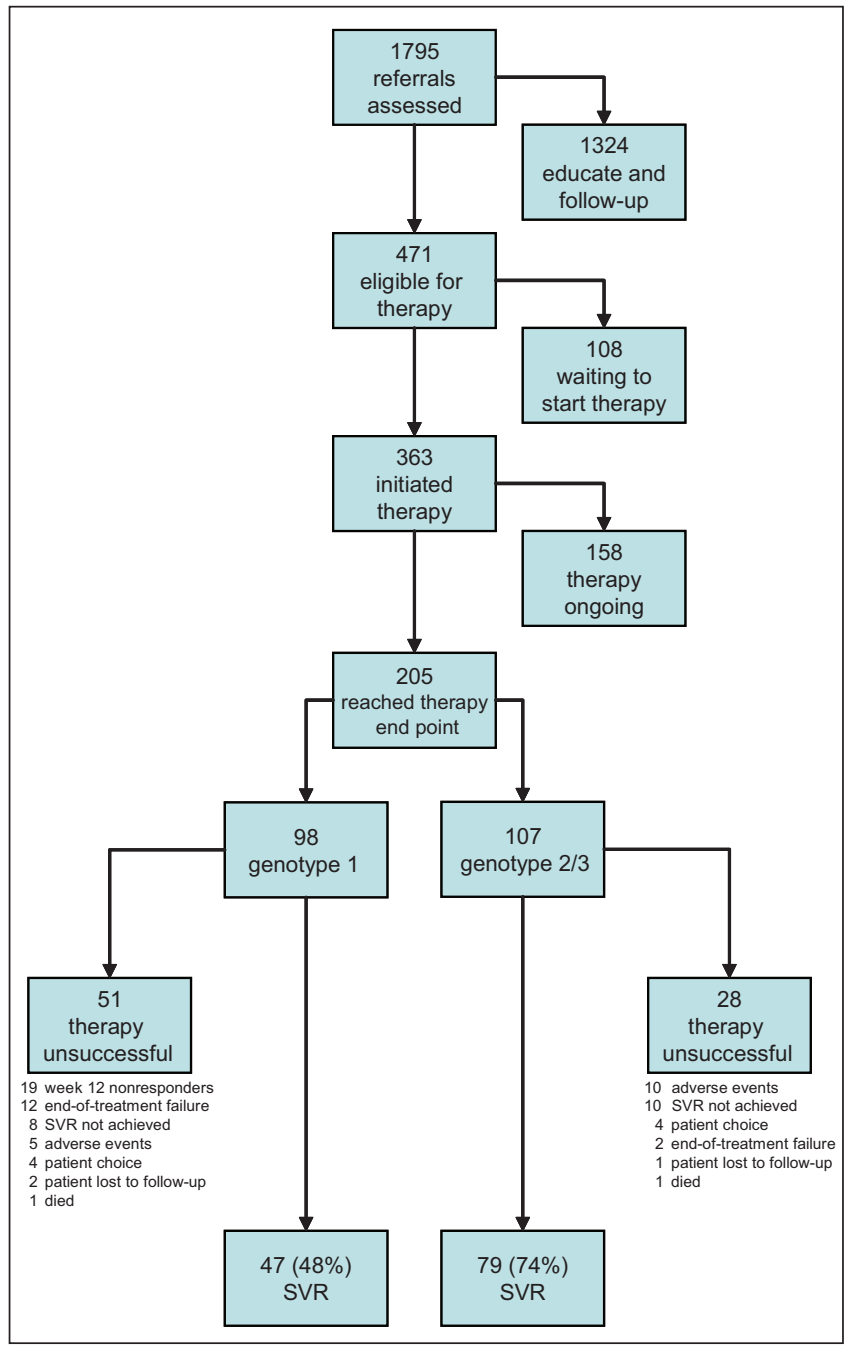

Figure 3) Clinic flow pathways and clinical outcomes of clients assessed in the project sites. SVR Sustained virological response

have not responded to previous treatment could be re-treated with more efficacious therapies, treatment inclusion criteria will likely be broadened and short-duration therapy may be offered in the near future $(9,22)$.

The present study had several limitations. First, the data collected were limited to basic clinical information and relied on client self-report of demographic data and risk behaviour. Second, data from secondary providers (eg, mental health and addictions) is not fully captured here. Third, the data presented here focus on clients that underwent HCV therapy. Little is known about the outcomes of the clients who received counselling and education.

Future challenges in HCV care include the integration of hepatitis services with those related to other bloodborne pathogens, such as HIV. It is estimated that between 30\% and $50 \%$ of HIV-infected IDU individuals are HCV coinfected and $5 \%$ to $10 \%$ of the HCV-infected population is coinfected with HIV $(23,24)$. Because most new HCV infections occur as a result of IDU, harm reduction programs aimed at reducing HIV burden may also reduce the incident $\mathrm{HCV}$ infection rate. Clinicians may need to alter their guidelines and emphasis to reach vulnerable populations that are disproportionately affected by HCV and HIV $(13,16,25)$. 


\section{CONCLUSIONS}

The present study findings suggest that a small investment in training, applied within an existing physical infrastructure, can significantly increase local expertise and capacity for $\mathrm{HCV}$ care. The project sites described here were successful in rural and small urban settings and produced HCV treatment outcomes comparable with large clinical trials. The public health nurse and physician partnership developed at the project sites facilitated the provision of locally accessible, integrated services to a population with complex medical needs and promoted efficient management of HCV. Future research should evaluate the application of public health nurse and physician partnerships to the management of other chronic diseases, especially in rural settings.

ACKNOWLEDGMENTS: The authors gratefully acknowledge the assistance and support of the following partners: Donna McNeill, Charles Mahoney, Pauline Melanson, Michelle Crosby, Lisa Chu, Diane Dagenais-Preston, Jane Carnahan-Schultz, Gayle Carrier, Christine Sorensen, Marilyn Triggs, Nora Walker, Tracy Christiansen, Patricia Strimm, Ilse Kuepper, Mary-Lea Penrose, Lawrence Fredeen, and the nurses, physicians and staff in the integrated hepatitis prevention and care projects, as well as the four participating British Columbia regional health authorities. The authors also wish to thank Ciro Panessa and Stephanie Harvard for editorial review and comments on earlier drafts. The comments of two anonymous reviewers are gratefully acknowledged.

FUNDING: Funding was provided by the British Columbia Ministry of Health and a Canadian Institutes of Health Research project grant (\#20R90726) to Mel Krajden.

\section{REFERENCES}

1. Remis R. A study to characterize the epidemiology of hepatitis C infection in Canada, 2002. Final Report. Ottawa: Health Canada, 2004

2. Seeff LB. Natural history of chronic hepatitis C. Hepatology 2002;36(5 Suppl 1):S35-46.

3. Freeman AJ, Dore GJ, Law MG, et al. Estimating progression to cirrhosis in chronic hepatitis $\mathrm{C}$ virus infection. Hepatology 2001;34(4 Pt 1):809-16

4. Leigh JP, Bowlus CL, Leistikow BN, Schenker M. Costs of hepatitis C. Arch Intern Med 2001;161:2231-7.

5. Fried MW, Shiffman ML, Reddy KR, et al. Peginterferon alfa-2a plus ribavirin for chronic hepatitis $\mathrm{C}$ virus infection. $\mathrm{N}$ Engl J Med 2002;347:975-82.

6. Manns MP, McHutchison JG, Gordon SC, et al. Peginterferon alfa-2b plus ribavirin compared with interferon alfa-2b plus ribavirin for initial treatment of chronic hepatitis C: A randomised trial. Lancet 2001;358:958-65.

7. Falck-Ytter Y, Kale H, Mullen KD, Sarbah SA, Sorescu L, McCullough AJ. Surprisingly small effect of antiviral treatment in patients with hepatitis C. Ann Intern Med 2002;136:288-92.
8. Fleming CA, Craven DE, Thornton D, Tumilty S, Nunes D. Hepatitis $C$ virus and human immunodeficiency virus coinfection in an urban population: Low eligibility for interferon treatment. Clin Infect Dis 2003;36:97-100.

9. Zeuzem S, Diago M, Gane E, et al, for the PEGASYS Study NR16071 Investigator Group. Peginterferon alfa-2a (40 kilodaltons) and ribavirin in patients with chronic hepatitis $\mathrm{C}$ and normal aminotransferase levels. Gastroenterology 2004;127:1724-32.

10. Deuffic-Burban S, Mohamed MK, Larouze B, Carrat F, Valleron AJ. Expected increase in hepatitis C-related mortality in Egypt due to pre-2000 infections. J Hepatol 2006;44:455-61.

11. Shepard CW, Finelli L, Alter MJ. Global epidemiology of hepatitis C virus infection. Lancet Infect Dis 2005;5:558-67.

12. Patrick DM, Tyndall MW, Cornelisse PG, et al. Incidence of hepatitis $\mathrm{C}$ virus infection among injection drug users during an outbreak of HIV infection. CMAJ 2001;165:889-95.

13. Wong T, Lee SS. Hepatitis C: A review for primary care physicians. CMAJ 2006;174:649-59. (Erratum in 2006;174:1450).

14. Brant L, Harris HE, Ramsay ME, Grieve R, Roberts J, for the HCV National Register Steering Group. Pathways of care and resource utilization in a national cohort of patients with transfusion-acquired hepatitis C. J Viral Hepat 2005;12:618-26.

15. Irving WL, Smith S, Cater R, et al. Clinical pathways for patients with newly diagnosed hepatitis $\mathrm{C}$ - what actually happens. J Viral Hepat 2006;13:264-71.

16. Sherman M, Bain V, Villeneuve JP, et al. The management of chronic viral hepatitis: A Canadian consensus conference 2004. Can J Gastroenterol 2004;18:715-28.

17. De Kaita K, Wong S, Renner E, Minuk GY. Treatment outcomes in a centralized specialty clinic for hepatitis $\mathrm{C}$ virus are comparable with those from clinical trials. Can J Gastroenterol 2006;20:87-90.

18. Lee SS, Bain VG, Peltekian K, et al, for the Canadian PEGASYS Study Group. Treating chronic hepatitis $\mathrm{C}$ with pegylated interferon alfa-2a $(40 \mathrm{KD})$ and ribavirin in clinical practice. Aliment Pharmacol Ther 2006;23:397-408. (Erratum in 2006;23:1029)

19. Hadziyannis SJ, Sette H Jr, Morgan TR, et al, for the PEGASYS International Study Group. Peginterferon-alpha2a and ribavirin combination therapy in chronic hepatitis $\mathrm{C}$ : A randomized study of treatment duration and ribavirin dose. Ann Intern Med 2004;140:346-55.

20. Monnet E, Collin-Naudet E, Bresson-Hadni S, et al. Place of residence and distance to medical care influence the diagnosis of hepatitis C: A population-based study. J Hepatol 2006;44:499-506.

21. Pawlotsky JM. Therapy of hepatitis C: From empiricism to eradication. Hepatology 2006;43(2 Suppl 1):S207-20.

22. Sherman M, Yoshida EM, Deschenes M, et al. Peginterferon alfa-2a (40KD) plus ribavirin in chronic hepatitis $C$ patients who failed previous interferon therapy. Gut 2006;55:1631-8.

23. Rhodes T, Platt L, Judd A, et al. Hepatitis C virus infection, HIV co-infection, and associated risk among injecting drug users in Togliatti, Russia. Int J STD AIDS 2005;16:749-54.

24. Spittal PM, Bruneau J, Craib KJ, et al. Surviving the sex trade: A comparison of HIV risk behaviours among street-involved women in two Canadian cities who inject drugs. AIDS Care 2003; 15:187-95.

25. Strader DB, Wright T, Thomas DL, Seeff LB, for the American Association for the Study of Liver Diseases. Diagnosis, management, and treatment of hepatitis C. Hepatology 2004;39:1147-71. 


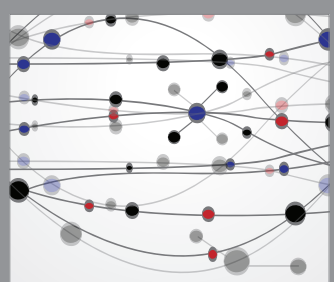

The Scientific World Journal
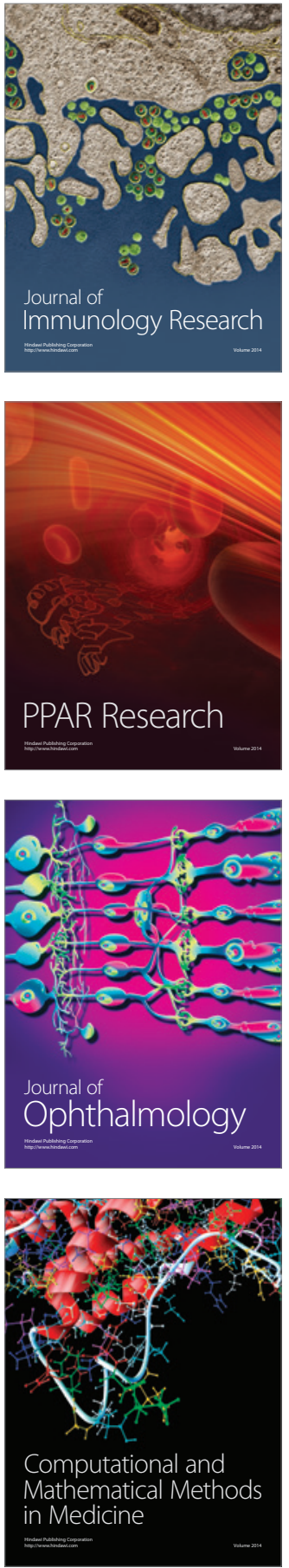

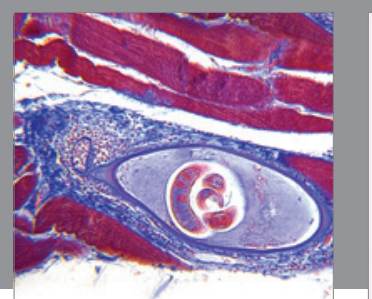

Gastroenterology Research and Practice

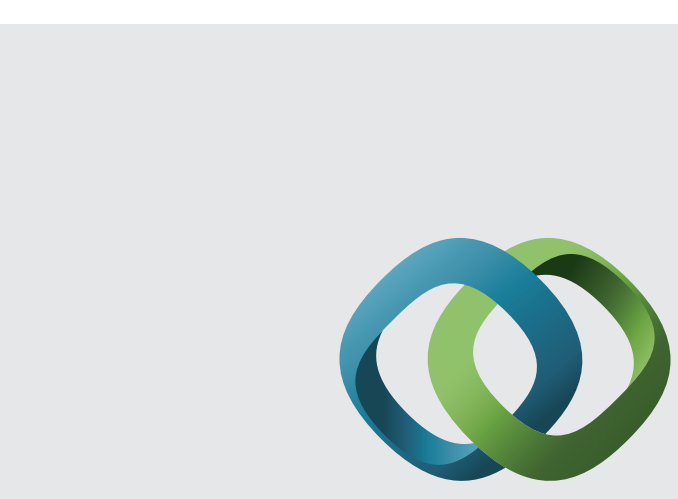

\section{Hindawi}

Submit your manuscripts at

http://www.hindawi.com
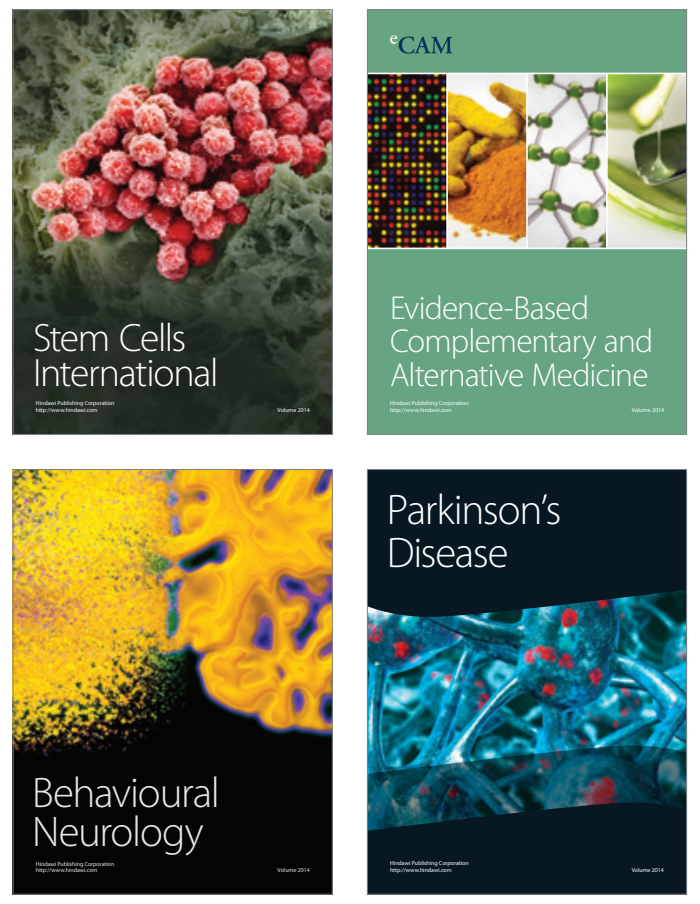
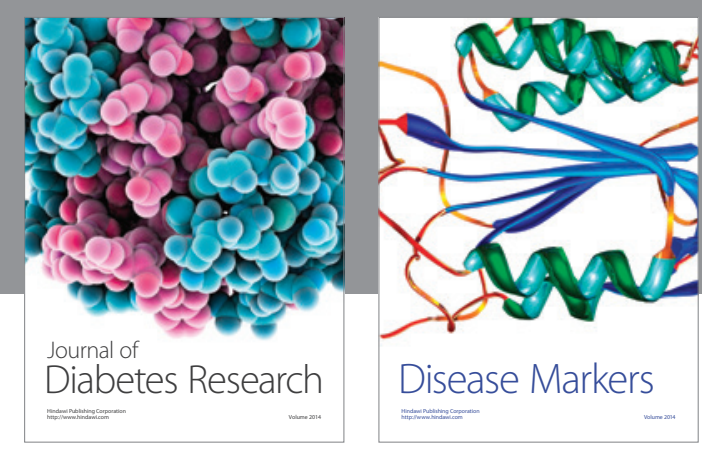

Disease Markers
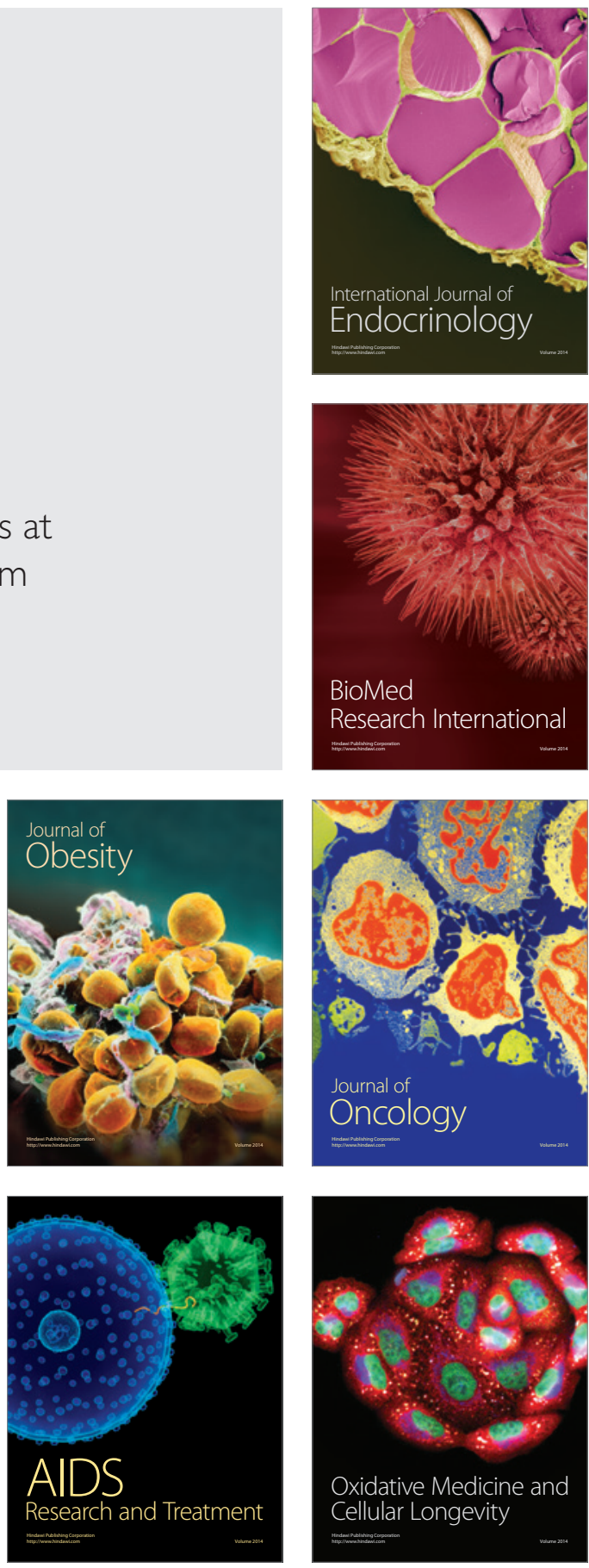